\title{
Effects of Short-term Drought Stress and Mechanical Harvesting on Sweet Orange Tree Health, Water Uptake, and Yield
}

\author{
Kelly T. Morgan ${ }^{1}$, Smita Barkataky, Davie Kadyampakeni, \\ Robert Ebel, and Fritz Roka \\ University of Florida, Southwest Florida Research and Education center, \\ 2685 SR 29N, Immokalee, FL 34142
}

Additional index words. Citrus sinensis, fruit detachment force, gleaning, leaf area index

Abstract. One of the primary reasons for the slow adoption of mechanical harvesting by Florida citrus growers is the physical injuries associated with it, including loss of leaves, twigs, flowers, and young fruits, limb breakage, and injuries to the bark and root. However, it has been shown that well-managed trees are capable of tolerating defoliation, limb loss, and root and bark injury caused by mechanical harvesting. Irrigation management is one of the most crucial factors that influence citrus tree health. A multiple-year field study was conducted on 'Valencia' sweet orange trees in a commercial citrus grove near Immokalee, FL, to determine the effect of initial tree canopy density and short-term drought stress on tree health, water uptake, and productivity of mechanically harvested trees. Three blocks were based on canopy density and overall appearance and indicated as low, moderate, and high canopy density. The experiment was laid in a split-plot design with four replications of six-tree plots of hand-harvested or mechanically harvested trees, taking drought stress or full irrigation as main treatments. The experimental design was repeated with trees in each plot of one of the three canopy density categories. After harvest, each six-tree plot was split into two three-tree subplots, where one subplot was drought-stressed and the other was fully irrigated. Harvesting was conducted in the Spring of 2010, 2011, and 2012 with the same experimental design and data collection procedures. The effects of short-term drought on water use and stem water potential were masked by heavy rains in Spring 2010 and thus no differences in the irrigation treatments were observed. In 2011 and 2012, stem water potential was unaffected by harvesting method. Water use was unaffected by harvesting method across the 3 years. Drought stress significantly increased pull force required to remove fruit and stem water potential after harvest. Although mechanically harvested trees lost leaf mass, with no rain before harvest, results from Spring 2011 and 2012 indicated that short-term drought stress had no effect on citrus leaf area irrespective of harvest method. Drought stress significantly increased fruit detachment force in low and moderate density but not in high-density trees resulting in increased force required to remove fruit from trees with moderate- to low-density canopies. Yield increased from 2010 to 2011 for mechanically harvested trees compared with hand-harvested for low-canopy density trees by $17 \%$ and moderate-canopy density trees by $8 \%$, whereas high-density plots indicated similar yield after mechanical harvesting. Comparatively, yield in 2012 decreased in the low and moderate densities compared with yield in 2011 but increased in the high density by $14 \%$ and $53 \%$ in hand- and machine-harvested trees, respectively. Despite finding 2- to 3-fold more debris in the mechanically harvested trees than the hand-harvested trees, yields and other measured parameters were unaffected suggesting that mechanical harvesting of citrus trees did not have an adverse effect on growth and production of well-watered citrus trees.

Florida citrus production is ranked number one in the United States, accounting for $63 \%$ of the 371,700-ha production area. California, Texas, and Arizona account for $32.5 \%, 3.3 \%$, and $1.6 \%$, respectively (USDA, 2011). The Florida citrus processing industry

Received for publication 26 Nov. 2013. Accepted for publication 2 Mar. 2014.

We acknowledge funding for this project by the State of Florida, Citrus Initiative.

${ }^{1}$ To whom reprint requests should be addressed; e-mail conserv@ufl.edu. faces daunting challenges as a result of citrus Huanglongbing (Candidatus Liberibacter asiaticus) (Morgan et al., 2009) and rising costs of hand-harvesting combined with decreasing availability of labor (Trimmer, 2012). Harvesting accounts for $\approx 50 \%$ of the total citrus production costs (Muraro, 2009; Whitney et al., 1996). Strong competition for laborers among different industries resulted in reduction of labor availability from 2002 to 2006 (Roka, 2004; Roka et al., 2000). Advantages of mechanical harvesting include reduced harvesting costs by 20 to 40 cents per box, which reduces the dependence on seasonal laborers thereby making the harvesting procedure relatively easier and cost-effective.

In the past 50 years, there has been commercial and research interest in use and improvement of mechanical harvesting to offset the costs associated with hand-harvesting (Ebel et al., 2012). Although mechanical harvesting of citrus was introduced to Florida in the mid-1950s (Futch et al., 2009), it has not been widely accepted in commercial orchards as a result of: 1) loss of leaves and twigs and scuffing of the bark on trunk and branches; 2) limb breakage and removal of flowers and young green fruit; and 3) exposure of shallow roots at the soil surface (Li et al., 2005). The primary concern of most Florida citrus growers was the effect of mechanical harvesting on long-term citrus tree health and productivity. However, long-term studies have demonstrated little effect on fruit yield by the mechanical harvesting method compared with hand-harvesting (Hedden et al., 1988). Studies have also indicated that well-managed, healthy citrus trees can sustain up to $25 \%$ defoliation without reducing canopy growth, fruit yield, and fruit quality (Yuan et al., 2005), in part because citrus can compensate for leaf loss by increasing photosynthesis of remaining leaves (Syvertsen, 1994). However, studies on the effect of water management associated with mechanical harvesting have not been conducted.

Citrus trees require a properly designed, operated, and maintained water management system to maximize yield and fruit quality (Zekri et al., 2009). Insufficient water supply results primarily in reduced growth, young fruit drop, and low sugar accumulation and reduced quality of the mature fruits (Enciso et al., 2008). Optimal irrigation also contributes to the efficiency of fertilizer programs resulting in increased yields and better tolerance to pests and stresses (Zekri et al., 2009). Lack of irrigation leads to reduced vegetative growth, limited number of new fruit-bearing branches, underdeveloped roots and leaves, which affect the number and size of the fruit and accentuates alternate bearing, i.e., high production 1 year followed by lower production the next year (Enciso et al., 2008).

Previous experiments on the effect of mechanical harvesting with trunk shakers (Burns et al., 2006; Li et al., 2005; Li and Syversten, 2005) and canopy shakers (Ebel et al., 2012) found little effect on citrus tree health that reduced long-term yield when they were conducted on well-watered trees with high canopy densities. Burns et al. (2006) did find that trees treated with an abscission agent [5-chloro-3-methyl-4-nitro1H-pyrazole (CMNP)] and harvested with a trunk shaker at low speed and handharvesting did not reduce yield the next year. However, the use of CMNP and trunk shakers at high speed was found to reduce followingyear yields in the same study. To evaluate the effect of short- and long-term water drought stress on mechanical harvesting, a 3-year field study was conducted to test the hypothesis that no significant injury by mechanical harvesting occurs to healthy, well-watered citrus trees that 
reduces long-term productivity. The objective of the current field study was to determine the effect of short-term drought stress before and/or after harvesting on: 1) fruit detachment force required to remove fruit at harvest; 2) tissue loss and canopy density after harvest; 3) stem water potential before and after harvest; 4) changes in water use; and 5) fruit yield associated with harvest method.

\section{Material and Methods}

Site. A commercial citrus orchard located $\approx 32 \mathrm{~km}$ south of the University of Florida, Southwest Florida Research and Education Center, near Immokalee, FL (lat. $26^{\circ} 21^{\prime} \mathrm{N}$, long. $81^{\circ} 23^{\prime} \mathrm{W}$ ) was selected for this study. Three portions of a block of mature 'Valencia' sweet orange (Citrus sinensis L.) growing on Malabar fine sand (Loamy, siliceous, hyperthermic Grossarenic Endoaqualfs) containing trees with three different tree canopy densities described below were selected for use in this study. Trees were inspected several times per year for the 3 years of the experiment to confirm that the trees were visually asymptomatic for Huanglongbing.

Treatments. The experimental design included three separate blocks with different tree densities (Fig. 1; low, moderate, and high). The three tree densities were because of their position in the landscape relative to the pond in Figure 1. The pond was dry during the Florida dry seasons (September to May) but held water during the rainy season (June to August) each year. An elevated water table during the rainy season produced trees of similar size but lower leaf density and yield with decreased distance to the pond. Within each tree density block, a factorial design of two irrigation treatments (irrigation main plots) and two harvesting treatments was established (Fig. 2). The trees were categorized into tree density blocks based on canopy density general tree appearance and cropload. The two irrigation main treatments were 1) no drought stress before harvest with irrigation applied up to date of harvest; and 2) drought stress before harvest with no irrigation $5 \mathrm{~d}$ before harvest. The two harvesting treatments were 1) machine-harvested using a pull-behind canopy shaker; and 2) hand-harvesting. In each tree density block, two sets of irrigation main plots were established with one of two irrigation treatments before harvest. Each plot consisted of six trees in the planted row and was replicated four times for a total of 16 plots per tree density block. After harvest, each irrigation main plot was split into two 3-tree irrigation subplots with one irrigation subplot receiving 1) irrigation immediately after harvesting (no stress); or 2) no irrigation for $8 \mathrm{~d}$ after harvest (stress) (Fig. 3). The two irrigation main plots-1) no water stress and 2) water stress - before harvest were separated into four irrigation subplots after harvest: 1) water stress before and after harvest; 2) water stress before harvest and no water stress after harvest; 3 ) no water stress before and after harvest; and 4) no water stress

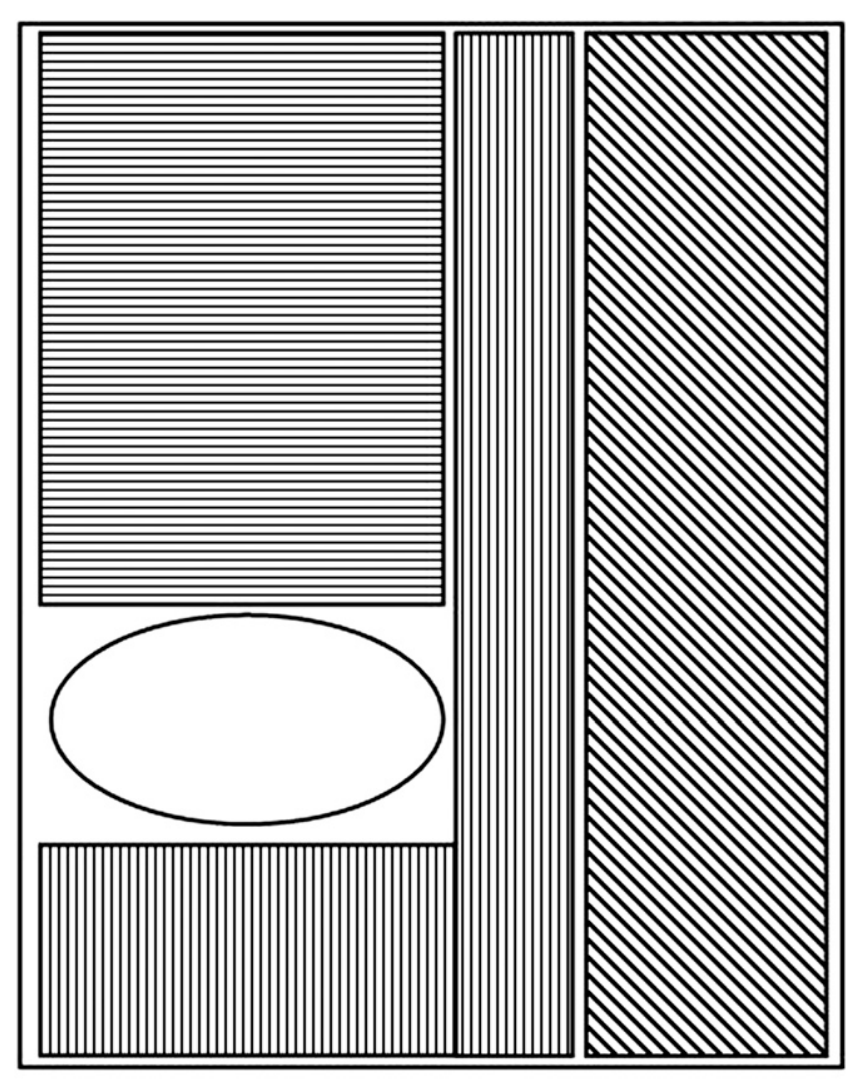

Low density

\section{Moderate density}

High density

Depression

Fig. 1. Map of the low-, moderate-, and high-density blocks.

before harvest and water stress after harvest. Detachment force required to remove fruit; weight of leaf, stem, and fruit debris on the ground after harvest; and harvested yield were measured for the two treatments before harvest. Leaf area index, stem water potential, and water use were measured before and after harvest for conditions 1 through 6 .

All trees received the same irrigation before start of the study treatments using full-circle microsprinklers. Because all trees were located in the same production area and under the same management, equal inputs can be assumed. The study was repeated in 3 consecutive years (2010, 2011, and 2012).

Fruit detachment force. On the day of harvest, five fruits were randomly selected from the second and the fifth trees of each plot (10 fruits per plot). Fruit detachment force was measured using a digital force gauge (Model Force Five; Wagner Instruments, Greenwich, CT; Hartmond et al., 2000).

Harvesting debris and leaf area index. The leaves, twigs, small stems, blooms, and immature fruits that fell from the tree during harvest were referred to as harvesting debris. A rectangular frame $(95 \mathrm{~cm} \times 95 \mathrm{~cm})$ was placed from the tree trunk to the tree drip line underneath the second and the fifth trees of each plot to catch material falling from a tree during harvest. The total amount of debris caught in the two frames represented the debris from that particular plot. Total harvest debris for each tree was calculated using the area under the tree canopy. The leaves were separated from the other debris and ovendried at $53{ }^{\circ} \mathrm{C}$ for $48 \mathrm{~h}$. The average dry weight of leaves and the average dry weight of the total debris were obtained for the handharvested and the mechanically harvested plots of all the three tree categories.

Leaf area index (LAI) was used to quantify initial tree condition before harvest and to determine effect of harvest method on tree canopy density. The LAI of the second and the fifth trees of each plot were measured using a SunScan canopy analysis system (Dynamax Inc., Houston, TX) between 1100 and $1300 \mathrm{HR}$ during sunny days. LAI measurements were taken $10 \mathrm{~d}$ before and $14 \mathrm{~d}$ after harvest from the four quadrants around a tree and averaged.

Stem water potential. Stem water potential $(\Psi)$ was measured using three leaves per 


\begin{tabular}{|c|c|c|c|c|c|c|c|c|c|c|}
\hline \multicolumn{11}{|c|}{ Row number } \\
\hline 1 & 2 & 3 & 4 & 5 & 6 & 7 & 8 & 9 & 10 & 11 \\
\hline 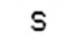 & s & $s$ & $\mathrm{~s}$ & $\mathrm{~s}$ & $\mathrm{~s}$ & $\mathrm{~s}$ & $S$ & s & $\mathrm{s}$ & \\
\hline$S$ & S & $S$ & $S$ & S & S & $S$ & $S$ & S & $S$ & \\
\hline $\begin{array}{l}S \\
P\end{array}$ & $\begin{array}{l}S \\
S\end{array}$ & $\begin{array}{l}S \\
S\end{array}$ & & $\begin{array}{l}S \\
S\end{array}$ & $\begin{array}{l}S \\
S\end{array}$ & $\begin{array}{l}S \\
S\end{array}$ & $\begin{array}{l}S \\
S\end{array}$ & $\begin{array}{l}S \\
S\end{array}$ & $\begin{array}{l}S \\
S\end{array}$ & \\
\hline $\begin{array}{c}T \\
0 / 0 T\end{array}$ & $\begin{array}{l}S \\
S\end{array}$ & $\begin{array}{l}S \\
S \\
\end{array}$ & & $\begin{array}{l}S \\
S \\
\end{array}$ & $\begin{array}{l}S \\
S\end{array}$ & $\begin{array}{l}S \\
S\end{array}$ & $\begin{array}{l}S \\
S\end{array}$ & $\begin{array}{l}S \\
S\end{array}$ & $\begin{array}{l}S \\
S\end{array}$ & \\
\hline$T$ & s & & & $T$ & s & $s$ & $s$ & $s$ & $s$ & S \\
\hline$T$ & S & & & O/OT & S & $\mathrm{S}$ & $\mathrm{S}$ & s & $\mathrm{S}$ & $s$ \\
\hline $0 / 8 T$ & S & & $S$ & $T$ & S & $\mathrm{s}$ & S & s & $\mathrm{s}$ & S \\
\hline$T$ & $s$ & & $T$ & $T$ & $s$ & $T$ & s & $s$ & $s$ & S \\
\hline$S$ & s & 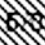 & $5 / 0 T$ & $0 / 8 T$ & $T$ & $0 / 8 T$ & s & s & $\mathrm{s}$ & \\
\hline $\mathrm{S}$ & S & 4 & $T$ & $T$ & $5 / 8 T$ & $T$ & S & $S$ & $S$ & \\
\hline$S$ & S & $S$ & $T$ & $s$ & $T$ & $T$ & $s$ & $s$ & $s$ & \\
\hline S & S & $\mathrm{s}$ & $5 / 8 T$ & & $T$ & O/OT & s & s & S & \\
\hline s & s & $S$ & $T$ & . & 5/0T & $T$ & s & s & $S$ & \\
\hline$S$ & s & $S$ & $S$ & & $T$ & $S$ & $S$ & $S$ & $S$ & \\
\hline$S$ & $S$ & $S$ & & & $S$ & $\mathrm{~S}$ & $\mathrm{~s}$ & $S$ & $\mathrm{~s}$ & $S$ \\
\hline $\mathrm{S}$ & $S$ & $\mathrm{~S}$ & & & $\mathrm{~S}$ & $\mathrm{~S}$ & $T$ & $S$ & $\mathrm{~s}$ & \\
\hline$S$ & $s$ & $s$ & & 4 & $S$ & $S$ & O/OT & $s$ & $S$ & \\
\hline$S$ & $S$ & $S$ & & $S$ & $S$ & $S$ & $T$ & $S$ & $S$ & \\
\hline$S$ & $S$ & $S$ & & $S$ & $S$ & $S$ & $T$ & $S$ & $s$ & \\
\hline$S$ & $S$ & $S$ & & $S$ & $S$ & $S$ & O/8T & $S$ & $\mathrm{~s}$ & \\
\hline $\mathrm{s}$ & $s$ & $S$ & $S$ & $S$ & $s$ & $S$ & $T$ & $s$ & $S$ & \\
\hline$T$ & $S$ & $S$ & $S$ & $S$ & $S$ & $S$ & $S$ & $S$ & $S$ & $S$ \\
\hline $5 / 0 T$ & $S$ & $S$ & $S$ & $S$ & $S$ & $s$ & $S$ & $S$ & $S$ & $s$ \\
\hline$T$ & $S$ & $S$ & $S$ & $S$ & $S$ & $T$ & $S$ & $S$ & $S$ & $S$ \\
\hline$T$ & $S$ & $S$ & $S$ & $S$ & $S$ & $5 / 8 T$ & $S$ & $s$ & $s$ & \\
\hline $5 / 8 \mathrm{~T}$ & $S$ & $S$ & $S$ & $S$ & $\mathrm{~s}$ & $T$ & $S$ & $S$ & $S$ & \\
\hline$T$ & $S$ & $S$ & $S$ & $S$ & $S$ & $T$ & $S$ & $S$ & $S$ & \\
\hline$S$ & $s$ & $S$ & $S$ & $S$ & $S$ & 5/OT & $S$ & $s$ & $s$ & \\
\hline$S$ & $S$ & $S$ & $S$ & $S$ & $S$ & $T$ & $S$ & $S$ & $S$ & \\
\hline $\mathrm{s}$ & $S$ & $\mathrm{~s}$ & $S$ & $S$ & $S$ & $S$ & $S$ & $S$ & $s$ & \\
\hline
\end{tabular}

Fig. 2. The irrigation main plots exemplified for the low-density block with eight hand-harvested and eight mechanically harvested plots.

tree randomly selected from the second and fifth trees of each plot (total six leaves per plot). Leaves were initially wrapped in plastic, then aluminum foil the day before data collection to allow the water potential of the leaves to equilibrate with the water potential of the stem. Like with LAI, $\Psi$ measurements were made at midday. Wrapped leaves were cut at the petiole with a razor blade and $\Psi$ was measured using a pressure chamber (Model 1000; PMS Instrument Co., Corvallis, OR) that was pressurized at $1 \mathrm{MPa} / 30 \mathrm{~s}$ using compressed nitrogen.

Water use. Sap flow sensors were used in one of the four replications of each tree category. Because the second and fifth trees of a plot represented two different irrigation treatments, sap flow sensors (Dynagage sap flow sensors; Dynamax Inc., Houston, TX) were installed in the second and the fifth trees of each selected plots and connected to a data logger (CR 1000; Campbell Scientific Inc., Logan, UT). Flow data obtained from the logger (in $\mathrm{g} \cdot \mathrm{h}^{-1}$ ) were then summed to water flow per unit stem area per unit time $\left(\mathrm{g} \cdot \mathrm{cm}^{-2} \cdot \mathrm{d}^{-1}\right)$.
Fruit yield. The pull-behind harvesters deposited harvested fruit on the ground. Thus, fruit from hand- and machine-harvested plots were picked off the trees or from the ground and placed into one or more designated tub(s). Four empty tubs were weighed and the average weight was considered as the approximate weight of an empty tub. The tubs containing harvested fruits were weighed and the fruit weight was calculated by subtracting average weight of an empty tub from the weight of the tub containing fruit. The fruit that remained on the trees after mechanical harvest were handharvested (gleaned fruit). The gleaned fruits were weighed and added to the mechanically harvested fruit weight to determine total yield. Percent mechanically harvested fruit and gleaned fruit were calculated using total harvested fruit.

Statistical analysis. Data for each tree canopy category were analyzed as a split plot design with irrigation treatment as the main plot and harvest method as the subplot using SAS (2011). The means for harvest method, canopy density, and irrigation treatment were separated using Duncan's multiple range test at $P \leq 0.05$.

\section{Results}

Fruit detachment force. Rain confounded the irrigation treatments in 2010; fruit detachment force (FDF) was not different between harvest methods and irrigation treatments although significant interactions between density by irrigation and harvest method by irrigation were observed (Table 1). The interaction means showed no differences between harvest methods or density as a function of irrigation (Table 2). The FDF was greater for water-stressed trees in 2011 and 2012 with no differences among harvest methods. Thus, good water management before hand or mechanical harvest should be a critical consideration to ensure ease of fruit detachment. There was no consistent trend in FDF between tree densities across the 3 years.

Harvesting debris and leaf area index. Nearly 3-fold increase in total debris (including bloom) and 2-fold increase in leaf debris were found with mechanical than hand-harvesting in 2010 and 2011 (Tables 1 and 3 ). The leaf and total debris in 2012 were similar for mechanically and hand-harvested 


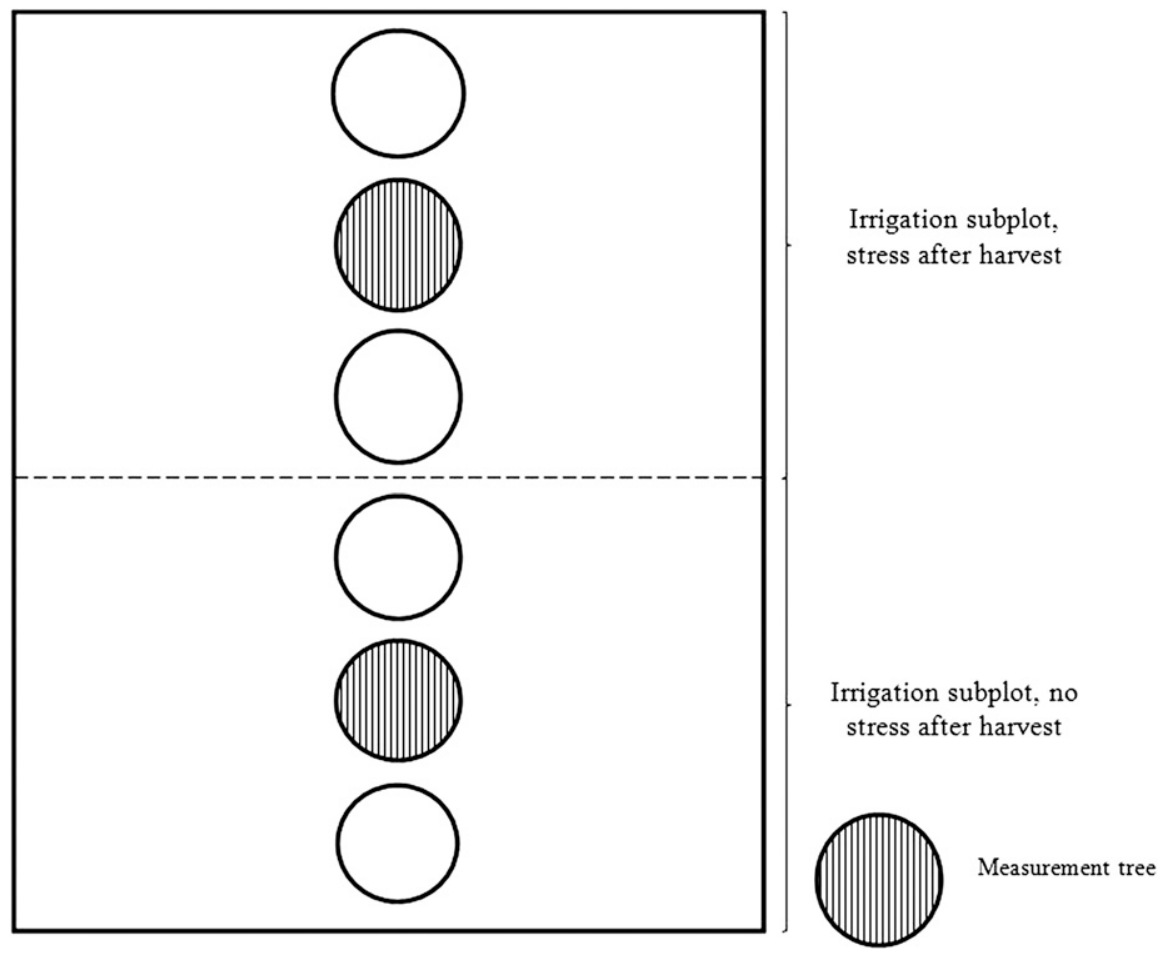

Fig. 3. Schematic describing an irrigation subplot. Each plot consisted of six trees and the subplot contained three trees.

trees. Significant differences $(P<0.05)$ were observed in LAI among the three tree densities in 2011 (Table 1). As expected, high- and moderate-density trees had greater LAI than low-density trees. Although LAI decreased after harvest for the high-density trees, no significant differences in LAI were found after harvest for the other two tree densities. Overall, the interaction means for LAI after harvest in 2011 suggested that LAI was unaffected by irrigation within a particular density (Table 2). In 2012 the LAI decreased by $1 \%$ to $22 \%$ in all categories, except for mechanically harvested low-density trees where the LAI increased by 5\% from 2011 post-harvest to 2012 before harvest (Table 1). The post-harvest LAI decreased by $15 \%$ and $27 \%$ for low density, $5 \%$ and $11 \%$ for moderate density, and by $\approx 38 \%$ and $43 \%$ for the hand and mechanically harvested tree categories (Table 1). The decline in the LAI could be ascribed to substantial defoliation during harvest and the removal of the fruit from the trees. These data indicate that citrus trees can lose a large amount of leaf mass with little effect on LAI and thus little reduction in photosynthetic capacity. The decline in LAI of mechanically harvested moderate-density tree was not expected in 2012 because we did not harvest from this category as a result of a mechanical problem with the harvester indicating that reduction in LAI can also be experienced from hand-harvesting that had been mechanically harvested in the past. The LAI before harvest was not different between the irrigation treatments across the 3 years. The LAI was similar between irrigation treatments in 2010 and 2012 , but $19 \%$, $21 \%$, and $15 \%$ greater LAI was observed in "non-stressed" trees, trees "water-stressed before harvest," and trees "water-stressed after harvest" than those trees "water stressed before and after harvest," respectively.

Stem water potential. Stem water potentials of water-stressed trees were greater than nonstressed trees before harvest in 2011. Stem water potential increased for all treatments in 2011 after harvest with greater $\Psi$ for stressed trees compared with non-stress trees. There was no difference in $\Psi$ by harvest method (Table 1). These data would infer increased water stress in citrus trees after harvest with greater stress caused by lack of irrigation immediately after harvest but no difference in stress caused by harvesting method. After harvest on 2012, $\Psi$ decreased for the waterstressed trees in low- and moderate-canopy densities owing to rainfall totaling $42 \mathrm{~mm}$ on 20 to 22 Apr. 2012, just a few days before taking the water potential measurements. Overall, greater $\Psi$ was observed in trees water-stressed after harvest and water-stressed before and after harvest compared with the trees water stressed before harvest and the nonstressed trees (well-watered).

Water use. There was no effect on tree water use in 2010 resulting from rainfall totaling $271 \mathrm{~mm}$ that masked the effects of short-term droughts, canopy density, or harvest method. Only $140 \mathrm{~mm}$ and $45 \mathrm{~mm}$ of rain fell during the same period in 2011 and 2012, respectively. In 2011, sap flow decreased for stressed treatments and were lower (lowdensity trees) or similar for the same treatments after harvest (Table 1). Water-stressed trees before harvest increased in sap flow after irrigation was resumed with similar water use observed for mechanically and hand-harvested trees. The highest sap flows, as expected, were noted in the non-stressed irrigated trees in all tree densities in 2012. Low-density category trees subjected to water stress $9 \mathrm{~d}$ before or after harvest did not show much change in sap flow despite lack of water. The well-watered trees (non-stressed) showed a fairly consistent pattern similar to that of trees water-stressed after harvest regardless of the harvest method or tree density. Thus, the study revealed that non-stressed trees and trees stressed after harvest in 2011 and 2012 had similar water use and this was confirmed in 2012 with the interaction effects observed between harvest method by irrigation and density by irrigation (Table 2), possibly because those trees stressed after harvest would now require less water with no fruit load indicating the potential for conserving water after harvest without affecting orchard productivity. On the other hand, trees water-stressed before harvest required more water to support the trees with fruit load and greater canopy. The trees under high density had larger canopies and leaf areas resulting in sap flows 2-fold that observed in the other two categories. There were clear differences in water use between water-stressed trees before and after harvest in 2011 and 2012 .

Fruit yield. The average fruit yield, irrespective of harvesting methods, was significantly higher in the high-canopy density trees compared with the low- and moderatedensity trees in 2010 (Table 3). In 2011, significant differences among tree canopy density categories were noted. No yield differences were observed between hand- and machine-harvested trees. No significant differences were found among irrigation 
Table 1. Orange tree water use, preharvest (PreHSWP) and post-harvest (post-HSWP) stem water potential, leaf area index before (LAIB) and after (LAIA) harvest, and fruit detachment force (FDF) in 2010, 2011, and 2012 as a function of canopy density, harvest method, and irrigation treatment.

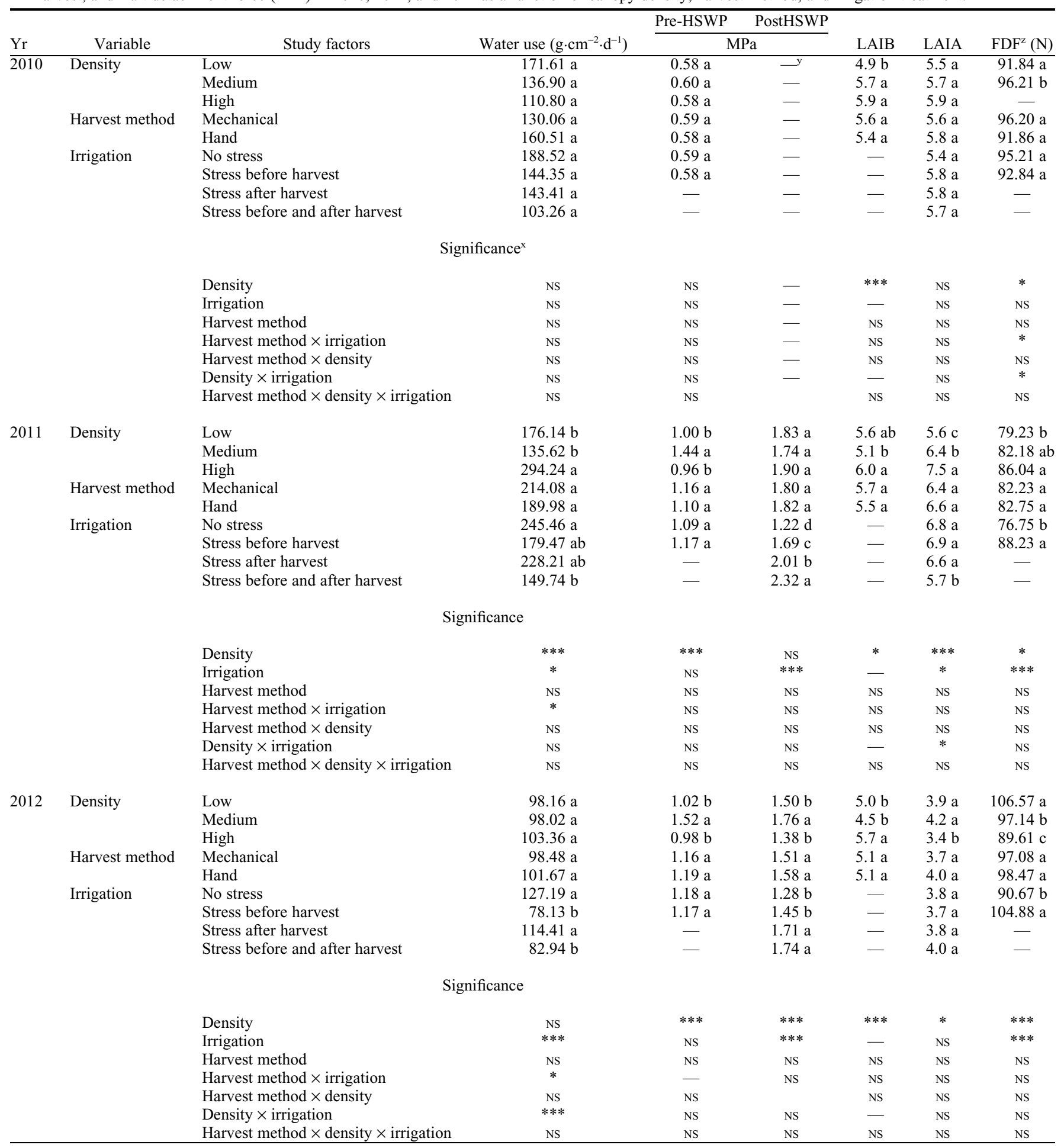

${ }^{\mathrm{z}} \mathrm{SWP}=$ stem water potential; LAIB $=$ leaf area index before harvest; LAIA = leaf area index after harvest; FDF $=$ fruit detachment force.

${ }^{\mathrm{y}}$ Not applicable.

${ }^{\mathrm{x}} \mathrm{NS}, *, * *, * *$ Nonsignificant or significant at $P<0.05,0.01$, or 0.001 , respectively. Means having the same letter within a column for a study factor are not significantly different at $P<0.05$.

treatments in either year for fruit weights, which were not removed by the mechanical harvester (glean fruit) (Table 3). In 2012, fruit yields declined by $4 \%$ to $23 \%$ for hand and mechanically harvested low-density trees and $17 \%$ for hand-harvested moderate-density trees compared with yields obtained in 2011 . However, the fruit yields for high-density trees increased by $14 \%$ and $53 \%$ for hand and mechanically harvested tree categories, respectively, over 2011 harvest. The yields were generally similar between the tree density categories in 2012 except for mechanically harvested high-density trees where 53\% greater fruit yield was collected compared with 2011. The mechanical harvesting left $\approx 50 \%$ to $60 \%$ of the fruit on the tree in the high density and between $20 \%$ and $40 \%$ in the low density (Table 3) in 2012. Lower harvester intensities (measured in cycles per second) used in this study were similar to those intensities used in experiments testing the effectiveness of abscission agents to aid release of fruit in mechanical harvesting. 
Table 2. Interaction means for density by irrigation, harvest method by irrigation, and irrigation by density for fruit detachment force (FDF) in 2010 , leaf area index (LAI) after harvest in 2011, and water use in 2012.

\begin{tabular}{|c|c|c|c|c|c|c|c|c|c|c|}
\hline Density & Irrigation & 2010 & Harvest method & Irrigation & 2010 & 2012 & Density & Irrigation & 2011 & 2012 \\
\hline & & FDF (N) & & & FDF (N) & $\begin{array}{l}\text { Sap flow } \\
\left(\mathrm{g} \cdot \mathrm{cm}^{-2} \cdot \mathrm{d}^{-1}\right)\end{array}$ & & & LAI & $\begin{array}{c}\text { Sap flow } \\
\left(\mathrm{g} \cdot \mathrm{cm}^{-2} \cdot \mathrm{d}^{-1}\right)\end{array}$ \\
\hline Low & No stress & $90.6 \mathrm{a}$ & Hand & No stress & $98.1 \mathrm{a}$ & $139.1 \mathrm{a}$ & Low & No stress & $5.6 \mathrm{bdc}$ & $116.8 \mathrm{ba}^{\mathrm{z}}$ \\
\hline Moderate & No stress & $101.0 \mathrm{a}$ & Hand & $\begin{array}{l}\text { Stress after } \\
\text { harvest }\end{array}$ & $-^{y}$ & $116.7 \mathrm{ba}$ & Low & $\begin{array}{l}\text { Stress after } \\
\text { harvest }\end{array}$ & $5.6 \mathrm{bdc}$ & $152.6 \mathrm{a}$ \\
\hline \multirow[t]{6}{*}{ Moderate } & $\begin{array}{l}\text { Stress before } \\
\text { harvest }\end{array}$ & $92.7 \mathrm{a}$ & Hand & $\begin{array}{l}\text { Stress before } \\
\text { and after } \\
\text { harvest }\end{array}$ & - & $78.1 \mathrm{ba}$ & Low & $\begin{array}{l}\text { Stress before } \\
\text { and after } \\
\text { harvest }\end{array}$ & $5.1 \mathrm{dc}$ & $43.7 \mathrm{c}$ \\
\hline & & & Mechanical & No stress & $93.5 \mathrm{a}$ & $112.9 \mathrm{ba}$ & Moderate & No stress & $7.6 \mathrm{a}$ & $146.0 \mathrm{a}$ \\
\hline & & & Mechanical & $\begin{array}{c}\text { Stress before } \\
\text { harvest }\end{array}$ & $90.4 \mathrm{a}$ & $96.9 \mathrm{ba}$ & Moderate & $\begin{array}{l}\text { Stress before } \\
\text { harvest }\end{array}$ & $7.1 \mathrm{a}$ & $50.8 \mathrm{c}$ \\
\hline & & & Mechanical & $\begin{array}{c}\text { Stress after } \\
\text { harvest }\end{array}$ & - & $112.2 \mathrm{ba}$ & Moderate & $\begin{array}{l}\text { Stress after } \\
\text { harvest }\end{array}$ & $7.6 \mathrm{a}$ & $149.1 \mathrm{a}$ \\
\hline & & & Mechanical & $\begin{array}{c}\text { Stress before } \\
\text { and after } \\
\text { harvest }\end{array}$ & - & $87.8 \mathrm{ba}$ & Moderate & $\begin{array}{l}\text { Stress before } \\
\text { and after } \\
\text { harvest }\end{array}$ & $7.6 \mathrm{a}$ & $71.5 \mathrm{bc}$ \\
\hline & & & & & & & High & $\begin{array}{l}\text { Stress before } \\
\text { and after } \\
\text { harvest }\end{array}$ & $4.5 \mathrm{~d}$ & $51.9 \mathrm{bac}$ \\
\hline
\end{tabular}

${ }^{\mathrm{z}}$ Letters followed by the same letter is the same column are not significantly different at $P=0.05$.

${ }^{\mathrm{y}}$ Not applicable.

Recovery rates in fruit from mechanically harvested trees are typically $80 \%$ to $95 \%$ with abscission agents (Burns et al., 2006; Ebel et al., 2012). Less aggressive canopy shaking without abscission agents to reduce damage to the trees resulted in increased cost of handharvesting fruit remaining in the trees after mechanical harvesting.

The interaction means for density by harvest method in 2010 showed 2- to 6-fold greater leaf and total debris in mechanically harvested trees compared with hand-harvested trees in all tree densities (Table 4). However, the substantial loss in leaves and stems by mechanically harvested tress did not appear to affect fruit yield in the following spring seasons because the trees regrew the tissue lost during the harvest.

\section{Discussion}

Plant water relations and fruit detachment. The effects of short-term drought on $\Psi$ and water use were masked in 2010 by heavy rains before the study period causing high water tables and reduced irrigation stress effects. As expected, short-term drought treatments before harvest reduced water use although this did not negatively affect the yields. However, water uptake increased after harvest when irrigation resumed. These observations are in agreement with those of several researchers who reported recovery of sweet orange trees in less than 1 week after resuming irrigation (Fereres et al., 1979; Melgar et al., 2010; Pérez-Pérez et al., 2008). Water use after harvest decreased similarly for both harvest methods. Using LAI, $\Psi$, and fruit detachment force in 2011 as baseline measurements, little effect of short-term drought stress was found on yield, $\Psi$, and water use of mechanicalharvested trees in 2012. Li and Syversten (2005) reported similar results for 'Valencia' and 'Hamlin' oranges where mechanical harvesting did not reduce transpiration and water use efficiency for well-watered, moderate- to high-density trees. However, the effect of shortterm droughts in 2011 and 2012 was $16 \%$ greater FDF in stressed than well-watered trees. Previous studies on FDF were conducted with well-watered trees of moderate to high canopy densities. The current study showed significant increases in FDF with decreases in canopy densities indicating that more force is required to remove fruit from trees with lower densities. Therefore, good irrigation management with adequate water within 5 to $10 \mathrm{~d}$ before harvest would lower the FDF, thereby making harvesting easier and more efficient. Additionally, more forceful removal is required for low-canopy density trees that could result in removal of higher percentage of vegetative tissue.

Leaf area, fruit yield, and harvesting debris. Results from Spring 2011 and 2012 indicated that short-term drought stress had no effect on citrus leaf area irrespective of harvest method. Mechanical harvesting had no effect on fruit yield over the 3 years. These observations are in agreement with Yuan et al. (2005) who found no decline in fruit yield in 'Valencia' and 'Hamlin' oranges when annual manual defoliations did not exceed $25 \%$ total canopy leaf area. Other researchers also reported very similar yields between handharvesting and mechanical harvesting for six to 10 seasons in Florida for high-density canopies (Moseley et al., 2012; Whitney and Wheaton, 1987). The increase in harvesting debris by mechanical over hand-harvesting is similar to results reported by Spann and Danyluk (2010) in central Florida for high-density canopies. They found 2.5 -fold increase in harvest debris by mechanical compared with hand-harvesting. Our study and others plus commercial experience have shown that with healthy well-managed trees, mechanically harvesting trees does not reduce yield or tree health (Burns et al., 2006; Melgar et al., 2010). However, the present study is the first to indicate that the interaction of water stress and canopy density did not negatively impact leaf area density or yield.

\section{Conclusions}

A study was conducted to determine the effect of initial tree canopy density and shortterm drought stress on tree health and productivity of mechanically and hand-harvested trees. Greater FDF was required to remove fruit from trees with water stress before harvest. Leaf area and yields of citrus trees were unaffected by harvesting method despite finding 2- to 3-fold more removal of vegetative tissue by mechanical harvesting for all tree densities, suggesting that mechanical harvesting of citrus trees did not adversely affect growth and production regardless of canopy density. Differences were observed in water use in 1 of 2 years not impacted by rainfall during the study period with greater water use by the hand-harvested trees. Water use decreased, and $\Psi$ after harvest increased with water stress. The effects of water stress and canopy density on mechanically harvested citrus trees were not previously determined. The results from this study indicate that irrigation schedule before harvest is 


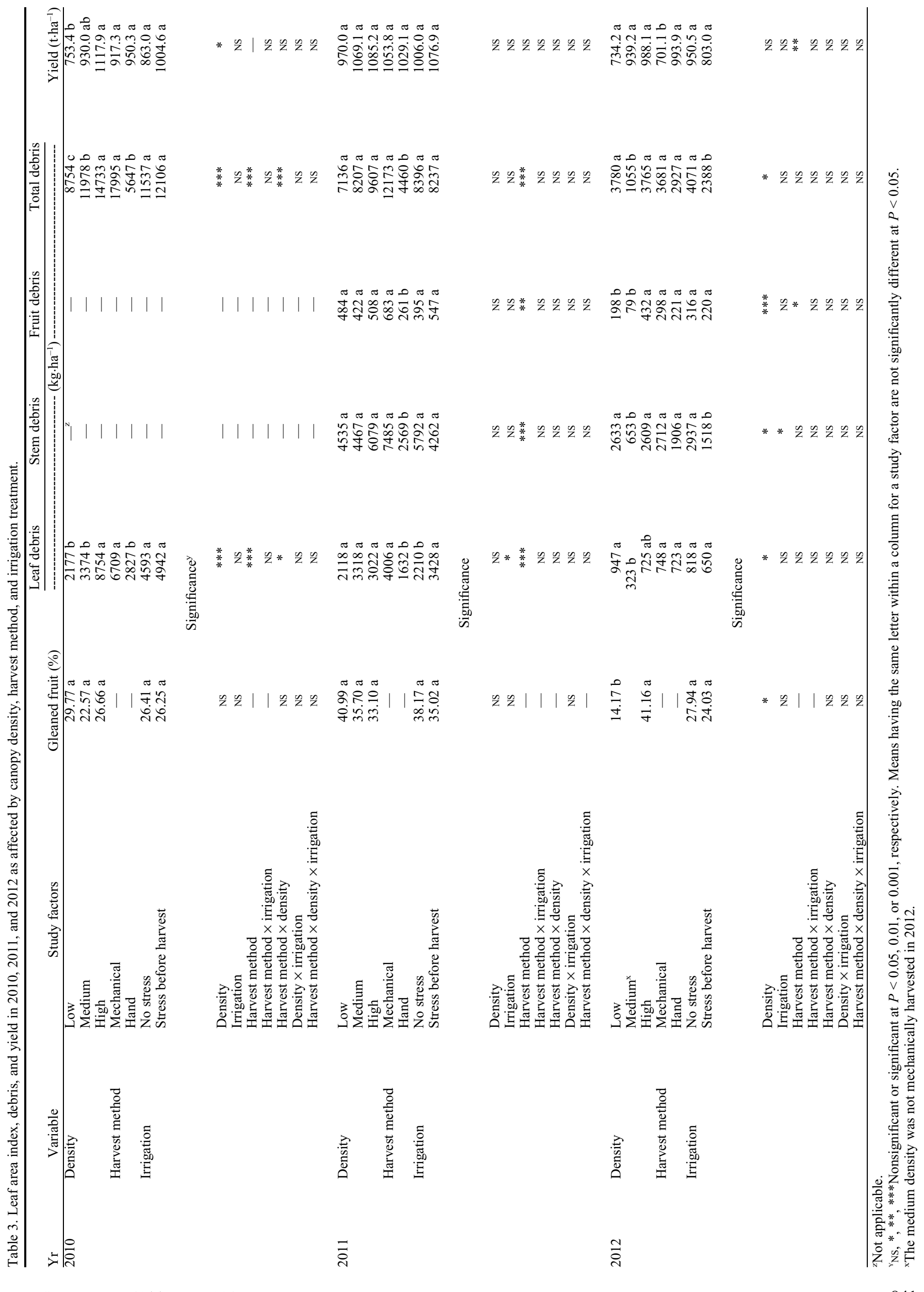

HortScience Vol. 49(6) June 2014 


\begin{tabular}{|c|c|c|c|}
\hline Density & $\begin{array}{l}\text { Harvest } \\
\text { method }\end{array}$ & $\begin{array}{l}\text { Leaf } \\
\text { debris }\end{array}$ & $\begin{array}{l}\text { Total } \\
\text { debris }\end{array}$ \\
\hline Low & Hand & $1,020 \mathrm{c}^{\mathrm{z}}$ & $5,107 \mathrm{~d}$ \\
\hline Moderate & Mechanical & $4,849 \mathrm{~b}$ & $23,195 \mathrm{a}$ \\
\hline High & Hand & $5,564 \mathrm{~b}$ & $5,565 \mathrm{~d}$ \\
\hline High & Mechanical & $11,944 \mathrm{a}$ & $11,944 \mathrm{c}$ \\
\hline
\end{tabular}

${ }^{\mathrm{z}}$ Means followed by the same letter is the same column are not significantly different at $P=0.05$.

critical in reducing the force required by mechanical harvesters to remove fruit and that less abscission agent would be required if the trees were well-irrigated before harvest. The study results also indicate that less water is used by citrus trees after harvest regardless of harvesting method, impacting irrigation scheduling, and reducing water demand estimations.

\section{Literature Cited}

Burns, J.K., F.M. Roka, K.T. Li, L. Pozo, and R.S. Buker. 2006. Late-season 'Valencia' orange mechanical harvesting with an abscission agent and low-frequency harvesting. HortScience 41:660-663.

Ebel, R.C., F.M. Roka, and K.T. Morgan. 2012. Field research with the abscission agent CMNP as an aid to mechanical harvesting of sweet orange. Acta Hort. 965:97-100.

Enciso, J., J. W. Sauls, R. P. Wiedenfeld, and S. D. Nelson. 2008. Impacts of irrigation on citrus in the lower Rio Grande Valley. Agrilife Ext.Texas A \& M System. B-620505-08.

Fereres, E., G. Cruz-Romero, G.J. Hoffmann, and S.L. Rawlins. 1979. Recovery of orange trees following severe water stress. J. Appl. Ecol. 16:833-842.

Futch, S.H., J.D. Whitney, J.K. Burns, and F.M. Roka. 2009. Harvesting: From manual to mechanical. HS-1017. Fla. Coop. Ext. Serv., Inst. Food Agr. Sci., Univ. Fla.

Hartmond, U., J.D. Whitney, J.K. Burns, and W.J. Kender. 2000. Seasonal variation in the response of 'Valencia' orange to two abscission compounds. HortScience 35:226229.
Hedden, S.L., D.B. Churchill, and J.D. Whitney. 1988. Trunk shakers for citrus harvesting - Part II: Tree growth, fruit yield and removal. Appl. Eng. Agr. 4:102-106.

Li, K.T. and J.P. Syversten. 2005. Mechanical harvesting has little effect on water status and leaf gas exchange in citrus trees. J. Amer. Soc. Hort. Sci. 130:661-666.

Li, K.T., J.P. Syversten, and J. Burns. 2005. Mechanical harvesting of Florida citrus trees has little effect on leaf water relations or return bloom. Proc. Fla. State Hort. Soc. 118:22-24.

Melgar, J.C., J.M. Dunlop, G. Albrigo, and J.P. Syvertsen. 2010. Winter drought stress can delay flowering and avoid immature fruit loss during late-season mechanical harvesting of 'Valencia' oranges. HortScience 45:271276.

Morgan, K.T., A.W. Schumann, W.S. Castle, E.W. Stover, D. Kadyampakeni, P. Spyke, F.M. Roka, R. Muraro, and R.A. Morris. 2009. Citrus production systems to survive greening: Horticultural practices. Proc. Fla. State Hort. Soc. 122:114-121.

Moseley, K.R., L.A. House, and F. Roka. 2012 Adoption of mechanical harvesting for sweet orange trees in florida: Addressing grower concerns on long-term impacts. Intl. Food Agribusiness Mgt. Rev. 15:83-98.

Muraro, R.P. 2009. Estimated average picking, roadisiding and hauling charges for Florida citrus, 2008-2009 season. 10 Feb. 2011. 15 Apr. 2010. <http://www.crec.ifas.ufl.edu/extension/ economics/pdf/Estimated_Average_Picking 2008 - 09.pdf>.

Pérez-Pérez, J.G., P. Romero, J.M. Navarro, and P. Botía. 2008. Response of sweet orange cv 'Lane late' to deficit irrigation in two rootstocks.
I. Water relations, leaf gas exchange and vegetative growth. Irrig. Sci. 26:415-425.

Roka, F.M. 2004. Dollars and cents of mechanical harvesting. Citrus Ind. 85:20-21.

Roka, F.M., G. Brown, and R. Muraro. 2000. Measuring performance of citrus harvesting systems. Proc. Intl. Soc. Citricult. 9:280-284.

SAS. 2011. The SAS system for Microsoft Windows-Release 9.3.188. Cary, NC.

Spann, T.M. and M.D. Danyluk. 2010. Mechanical harvesting increases leaf and stem debris in loads of mechanically harvested citrus fruit. HortScience 45:1297-1300.

Syvertsen, J.P. 1994. Partial shoot removal increases net $\mathrm{CO}_{2}$ assimilation and alters water relations of Citrus seedlings. Tree Physiol. 14:497-508.

Trimmer, M.C. 2012. Successful abscission agent development and commercialization in Florida oranges. Acta Hort. 965:91-96.

USDA. 2011. Florida citrus statistics 2009-2010. Fla. Dep. Agr. Consumer Serv., Tallahassee, FL.

Whitney, J. and T. Wheaton. 1987. Shakers affect Florida orange fruit yields and harvesting efficiency. Appl. Eng. Agr. 3:20-24.

Whitney, J.D., T.A. Wheaton, W.S. Castle, and D.P.H. Tucker. 1996. Orange grove factors affect manual harvesting rates. Trans. Amer. Soc. Agr. Eng. 39:399-405.

Yuan, R., F. Alferez, I. Kostenyuk, S. Singh, J.P. Syvertsen, and J.K. Burns. 2005. Partial defoliation can decrease average leaf size but has little effect on orange tree growth, fruit yield and juice quality. HortScience 40:20112015.

Zekri, M., T.A. Obreza, and R. Koo. 2009. Irrigation, nutrition, and citrus fruit quality. SL 207, Fla. Coop. Ext. Serv., Inst. Food Agr. Sci., Univ. Fla. 